PREPARED FOR THE U.S. DEPARTMENT OF ENERGY, UNDER CONTRACT DE-AC02-76CH03073

PPPL-3849

PPPL-3849

UC-70

\title{
Analysis of 4-strap ICRF Antenna Performance in Alcator C-Mod
}

\section{by}

G. Schilling, S.J. Wukitch, R.L. Boivin, J.A. Goetz, J.C. Hosea, J.H. Irby, Y. Lin, A. Parisot, M. Porkolab, J.R. Wilson, and the Alcator C-Mod Team

July 2003
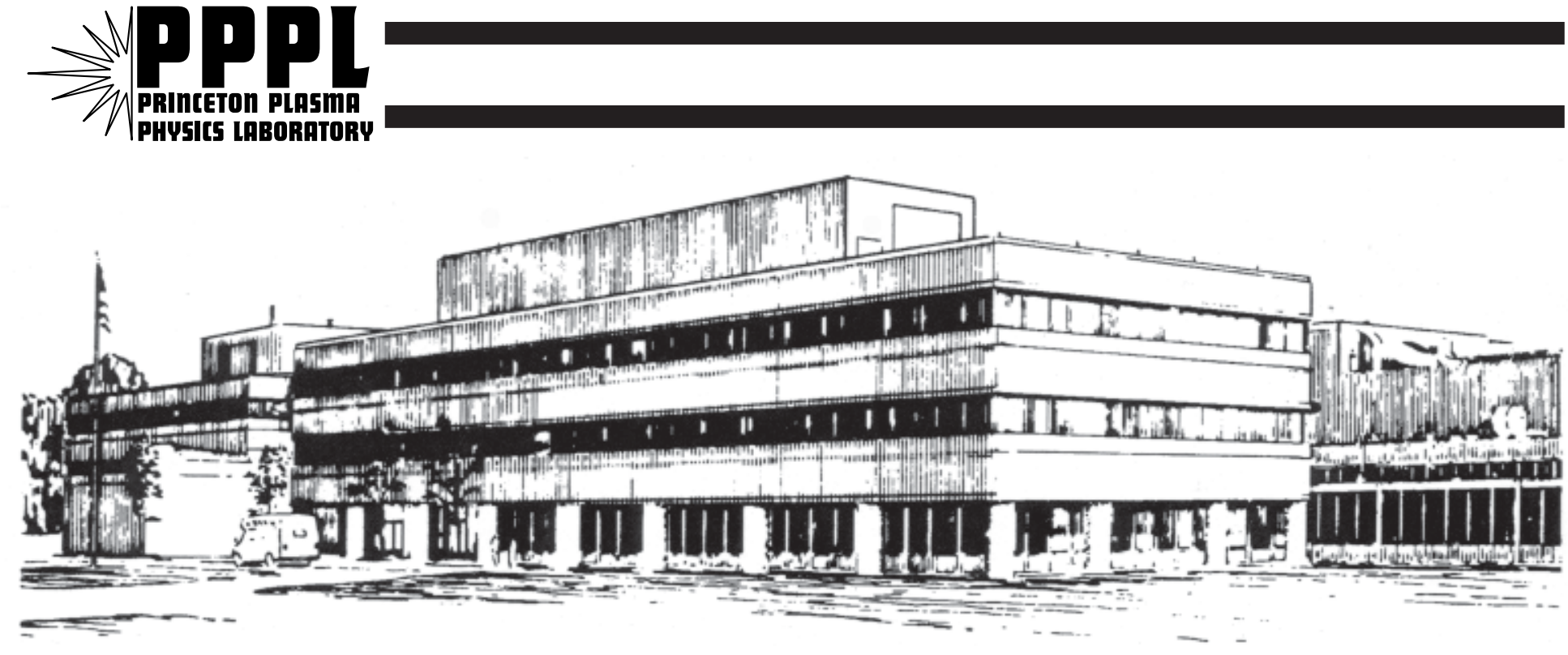

PRINCETON PLASMA PHYSICS LABORATORY PRINCETON UNIVERSITY, PRINCETON, NEW JERSEY 


\section{PPPL Reports Disclaimer}

This report was prepared as an account of work sponsored by an agency of the United States Government. Neither the United States Government nor any agency thereof, nor any of their employees, makes any warranty, express or implied, or assumes any legal liability or responsibility for the accuracy, completeness, or usefulness of any information, apparatus, product, or process disclosed, or represents that its use would not infringe privately owned rights. Reference herein to any specific commercial product, process, or service by trade name, trademark, manufacturer, or otherwise, does not necessarily constitute or imply its endorsement, recommendation, or favoring by the United States Government or any agency thereof. The views and opinions of authors expressed herein do not necessarily state or reflect those of the United States Government or any agency thereof.

\section{Availability}

This report is posted on the U.S. Department of Energy's Princeton Plasma Physics Laboratory Publications and Reports web site in Fiscal Year 2003. The home page for PPPL Reports and Publications is: http://www.pppl.gov/pub_report/

DOE and DOE Contractors can obtain copies of this report from:

U.S. Department of Energy

Office of Scientific and Technical Information

DOE Technical Information Services (DTIS)

P.O. Box 62

Oak Ridge, TN 37831

Telephone: (865) 576-8401

Fax: (865) 576-5728

Email: reports@adonis.osti.gov

This report is available to the general public from:

National Technical Information Service

U.S. Department of Commerce

5285 Port Royal Road

Springfield, VA 22161

Telephone: $1-800-553-6847$ or

(703) $605-6000$

Fax: (703) 321-8547

Internet: http://www.ntis.gov/ordering.htm 


\title{
Analysis of 4-strap ICRF Antenna Performance in Alcator C-Mod
}

\author{
G. Schilling ${ }^{1}$, S. J. Wukitch ${ }^{2}$, R. L. Boivin ${ }^{3}$, J. A. Goetz ${ }^{4}$, J. C. Hosea ${ }^{1}$, \\ J. H. Irby ${ }^{2}$, Y. Lin' ${ }^{2}$, A. Parisot ${ }^{2}$, M. Porkolab ${ }^{2}$, J. R. Wilson ${ }^{1}$, and the \\ Alcator C-Mod Team
}

${ }^{I}$ Princeton University Plasma Physics Laboratory, Princeton NJ 08543, ${ }^{2}$ MIT Plasma Science and Fusion Center, Cambridge, MA 02139, ${ }^{3}$ General Atomics, San Diego CA 92186, ${ }^{4}$ University of Wisconsin, Madison WI 53706

\begin{abstract}
A 4-strap ICRF antenna was designed and fabricated for plasma heating and current drive in the Alcator C-Mod tokamak. Initial upgrades were carried out in 2000 and 2001, which eliminated surface arcing between the metallic protection tiles and reduced plasma-wall interactions at the antenna front surface. A boron nitride septum was added at the antenna midplane to intersect electric fields resulting from rf sheath rectification, which eliminated antenna corner heating at high power levels. The current feeds to the radiating straps were reoriented from an $\mathbf{E} \| \mathbf{B}$ to $\mathbf{E} \square \mathbf{B}$ geometry, avoiding the empirically observed $\sim 15 \mathrm{kV} / \mathrm{cm}$ field limit and raising antenna voltage holding capability. Further modifications were carried out in 2002 and 2003. These included changes to the antenna current strap, the boron nitride tile mounting geometry, and shielding the BN-metal interface from the plasma. The antenna heating efficiency, power and voltage characteristics under these various configurations will be presented.
\end{abstract}

\section{INTRODUCTION}

The antenna design provides four vertical current straps in a configuration that allows efficient heating as well as providing a directed launched wave spectrum for current drive by changes in current strap phasing. ${ }^{1}$ An antenna's ability to deliver useful power to the plasma may be limited by the injection of impurities into the plasma or by arcing at high voltage limits. The 4-strap antenna power capability has increased from an initial value of $5 \mathrm{MW} / \mathrm{m}^{2}$ to $\sim 11 \mathrm{MW} / \mathrm{m}^{2}$ by eliminating impurity generation and improving high voltage handling. ${ }^{2,3,4}$

\section{IMPURITY GENERATION BY PLASMA-FACING SURFACE INTERACTIONS}

Initial antenna operation in 1999 resulted in high levels of metallic impurity influx at heating power levels above $\sim 1.3 \mathrm{MW}$. The impurity source was identified from the melt damage found upon inspection after the initial commissioning campaign. The molybdenum tiles on separate ground elements had melt damage, while those on the same ground element did not. This suggests 
a voltage was being developed across tiles on separate ground elements. Induced RF currents of $\sim 25$ A resulted in a tile-tile potential of $\sim 100 \mathrm{~V}$ at $78 \mathrm{MHz}$, sufficient to arc across the gaps under the local edge plasma conditions. The gaps were short-circuited in 2000 with stainless steel straps installed underneath the plasma protection tiles, eliminating this problem.

Operation with the metal plasma-facing components was satisfactory, but the level of Mo impurity at the plasma core was found to scale with the rf power. Although the source rate was low, plasma screening was poor. ${ }^{5}$ The antenna's plasma protection tiles were therefore changed from the original molybdenum to boron nitride. No deleterious effects have been observed on plasma operation resulting from the boron nitride.

A new front surface interaction limit appeared later in 2000 above 2.5 MW. Camera images of ICRF operation revealed antenna side and corner hot spots that were aligned along the edge magnetic field lines and resulted in impurity injection and disruption. An analysis of the hot spot mechanism suggests that the tokamak's field line pitch in front of the antenna results in

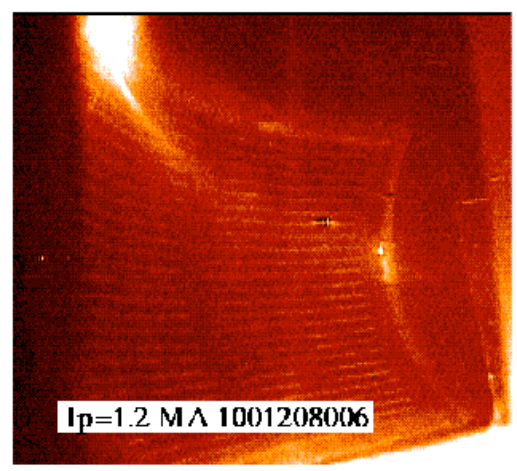
nonzero rf magnetic flux linkage to tokamak field lines connecting antenna surfaces. The resulting rf electric field expels electrons, and plasma neutrality results in ion acceleration leading to an enhanced sheath potential. ${ }^{6}$ All front protection tiles were realigned with side tiles, all remaining exposed metal surfaces were covered with boron nitride or removed, and a central boron nitride septum was installed to reduce the tokamak field line connection length.

FIGURE 3. Antenna front surface hotspots

Several of the top and bottom tiles fractured during the 2002 run period, with the fragments falling through the plasma into the divertor chamber. The fragments appeared not to have a major impact on the plasma, but the newly exposed metal surfaces reduced the antenna power level before metallic impurity injection set in once more. Disruption forces induced in the metal mounting structure were transmitted to the boron nitride, which yielded under tensile stress. The tiles and their fasteners were redesigned, and no losses have been observed in 2003 so far.

RF-induced arcing was detected in the metal spine supporting the central septum tiles. This was originally designed with slots to reduce induced currents, but sufficient rf voltage developed across the slots in $(0,0,0,0)$ phased operation to arc across the gaps. A new spine without slots was fabricated, and operation in 2003 so far has been successful. 


\section{ARCING IN ANTENNA INTERNAL STRUCTURE}

During the 1999 operation arcing was observed along the direction of the tokamak magnetic field between the high voltage portion of the antenna current straps and adjacent resistive terminations of the Faraday shields. Grounded stainless steel cups were placed around the base of the Faraday shield rods to protect the resistive terminations in $2000 .^{7}$ Subsequent inspections showed no damage.

Extensive arc damage was observed in 2000 between the striplines feeding rf current to the antenna straps, in a direction along the tokamak edge magnetic field. An effective stripline voltage limit of $\sim 15-20 \mathrm{kV}$ in plasma $(45 \mathrm{kV}$ in vacuum) limited the antenna heating power to $\sim 2.5 \mathrm{MW}$. This corresponded to an empirical electric field limit of $\sim 15 \mathrm{kV} / \mathrm{cm}$ under the local conditions, i.e. $\mathbf{E} \mid \mathbf{B}$, and plasma edge neutral gas pressure up to $\sim 0.5 \mathrm{mTorr}$. The mechanism for this breakdown is not clear. Field emission initiation requires local field strengths considerably higher than those present. For gas breakdown, the Paschen curve minimum is $\sim$ Torr-cm, while at the antenna we have $\sim$ mTorr-cm, with mean free paths much greater than the electrode spacing. Multipactoring initiation would require lower electric fields or greater path lengths.

The striplines had been designed with $\mathbf{E} \| \mathbf{B}$ in order to achieve maximum compactness, but a redesign was performed in 2001 to reorient the striplines to an $\mathbf{E} \square \mathbf{B}$ configuration. High voltage gaps were increased to reduce electric fields, and in the case of arcing at the current strap crossover, electrodes were reshaped to reorient the region of highest field.
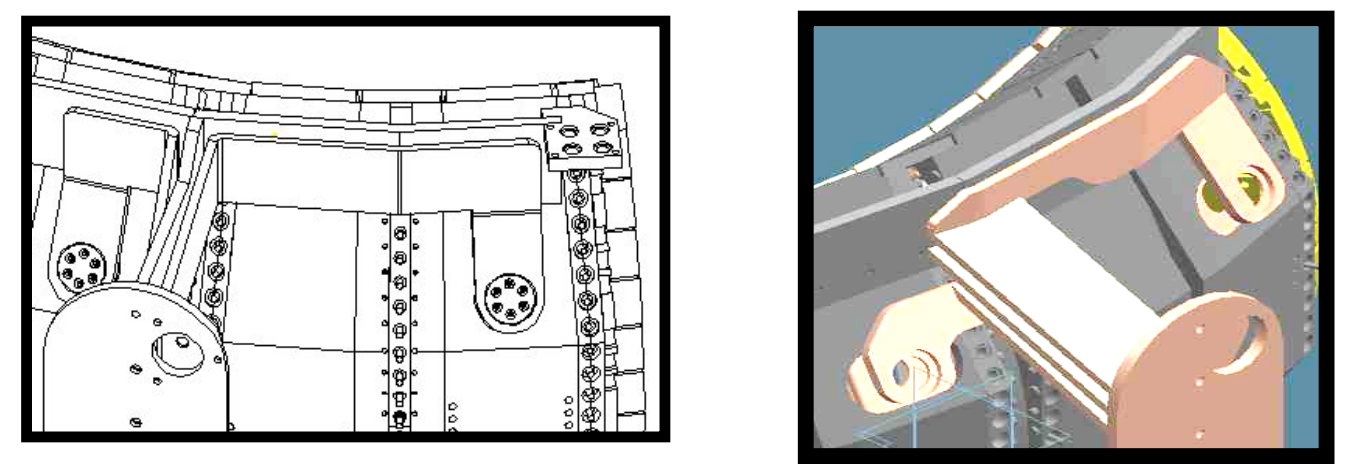

FIGURE 2. Original $\mathbf{E} \mid \mathbf{B}$ current feed design (left) and modified $\mathbf{E} \square \mathbf{B}$ design (right). The tokamak magnetic field is roughly horizontal on left, and rises at $\sim 30^{\circ}$ on right.

Series arcing was observed in 2002 in bolted contacts both in the current feeds and the antenna mounting plate. These have been redesigned with more bolts, improved mating surfaces, and copper plating where needed to improve electrical contact. 


\section{SUMMARY}

C-Mod has presented a challenge to install a high power ( 4 MW) 4-strap ICRF antenna in a tight space. Modifications have been made to the antenna plasma-facing surfaces and the internal current-carrying structure. At the present time the antenna has performed up to $3 \mathrm{MW}$ into plasma with heating phasing, with good efficiency and no deleterious effects.
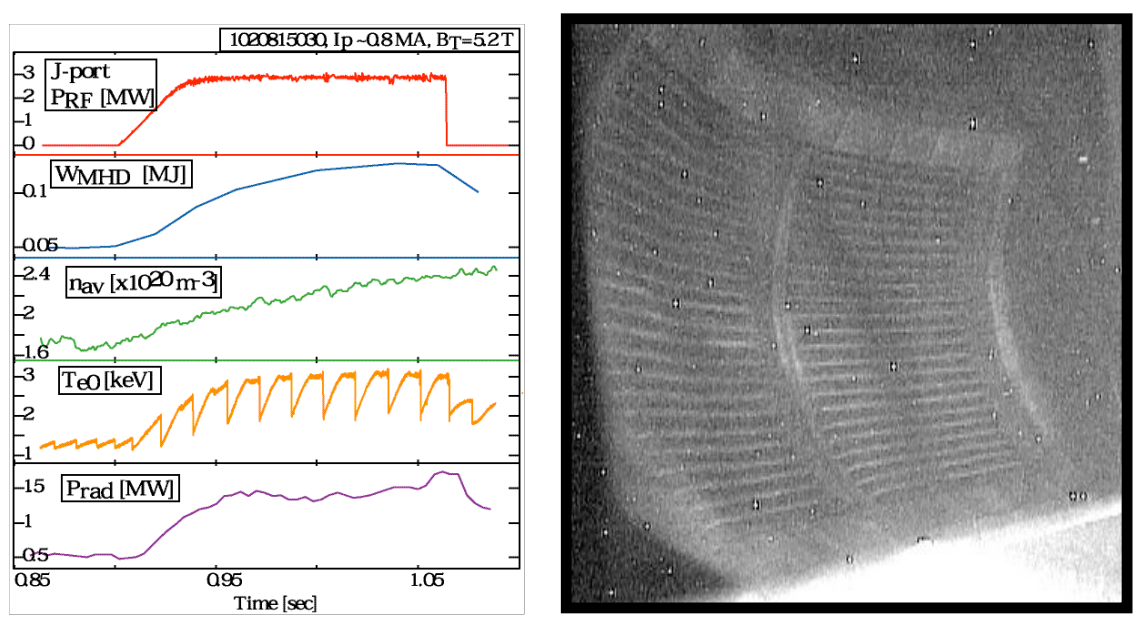

FIGURE 4.

3 MW pulse into C-Mod.

\section{ACKNOWLEDGEMENTS}

Work supported by US DoE Contract DE-AC02-76-CH0-3073 and Cooperative Agreement DE-FC02-99ER54512. Engineering support by W. Beck and R. Vieira, MIT PSFC, is gratefully appreciated.

\section{REFERENCES}

${ }^{1}$ G. Schilling et al., "Extension of Alcator C-Mod's ICRF Experimental Capability,” Proceedings of the $13^{\text {th }}$ Topical Conference on Radio Frequency Power in Plasmas, Annapolis MD, April 1999, 429-432.

${ }^{2}$ G. Schilling et al., "Upgrades to the 4-strap ICRF Antenna in Alcator C-Mod," Proceedings of the $14^{\text {th }}$ Topical Conference on Radio Frequency Power in Plasmas, Oxnard CA, May 2001, 186-189.

${ }^{3}$ S. J. Wukitch et al., "Results and Status of the Alcator C-Mod Tokamak," Proceedings of the $19^{\text {th }}$ IEEE/NPSS Symposium on Fusion Engineering, Atlantic City NJ, January 2002, 290-295.

${ }^{4}$ S. J. Wukitch et al., "Performance of a Compact Four-Strap Fast Wave ICRF Antenna," presented at the19th IAEA Fusion Energy Conference, Lyon, France, 14 - 19 October 2002, FT/P1-14.

${ }^{5}$ B. Lipschultz et al., "A Study of Molybdenum Influxes and Transport in Alcator C-Mod," Nuclear Fusion 41, (2001) 585.

${ }^{6}$ J. W. Myra and D. A. D'Ippolito, "Far Field ICRF Sheath Formation on Walls and Limiters," Proceedings of the Tenth Topical Conference on Radio Frequency Power in Plasmas, Boston MA, April 1993, 421-424.

7J. A. Goetz et al., "Operation of the Alcator C-Mod 4-Strap Antenna," presented at the $42^{\text {nd }}$ Annual Meeting of the APS Division of Plasma Physics, Quebec City, Canada, October 2000. 


\section{External Distribution}

Plasma Research Laboratory, Australian National University, Australia

Professor I.R. Jones, Flinders University, Australia

Professor João Canalle, Instituto de Fisica DEQ/IF - UERJ, Brazil

Mr. Gerson O. Ludwig, Instituto Nacional de Pesquisas, Brazil

Dr. P.H. Sakanaka, Instituto Fisica, Brazil

The Librarian, Culham Laboratory, England

Mrs. S.A. Hutchinson, JET Library, England

Professor M.N. Bussac, Ecole Polytechnique, France

Librarian, Max-Planck-Institut für Plasmaphysik, Germany

Jolan Moldvai, Reports Library, Hungarian Academy of Sciences, Central Research Institute for Physics, Hungary

Dr. P. Kaw, Institute for Plasma Research, India

Ms. P.J. Pathak, Librarian, Institute for Plasma Research, India

Ms. Clelia De Palo, Associazione EURATOM-ENEA, Italy

Dr. G. Grosso, Instituto di Fisica del Plasma, Italy

Librarian, Naka Fusion Research Establishment, JAERI, Japan

Library, Laboratory for Complex Energy Processes, Institute for Advanced Study, Kyoto University, Japan

Research Information Center, National Institute for Fusion Science, Japan

Dr. O. Mitarai, Kyushu Tokai University, Japan

Dr. Jiangang Li, Institute of Plasma Physics, Chinese Academy of Sciences, People's Republic of China

Professor Yuping Huo, School of Physical Science and Technology, People's Republic of China

Library, Academia Sinica, Institute of Plasma Physics, People's Republic of China

Librarian, Institute of Physics, Chinese Academy of Sciences, People's Republic of China

Dr. S. Mirnov, TRINITI, Troitsk, Russian Federation, Russia

Dr. V.S. Strelkov, Kurchatov Institute, Russian Federation, Russia

Professor Peter Lukac, Katedra Fyziky Plazmy MFF UK, Mlynska dolina F-2, Komenskeho Univerzita, SK-842 15 Bratislava, Slovakia

Dr. G.S. Lee, Korea Basic Science Institute, South Korea

Institute for Plasma Research, University of Maryland, USA

Librarian, Fusion Energy Division, Oak Ridge National Laboratory, USA

Librarian, Institute of Fusion Studies, University of Texas, USA

Librarian, Magnetic Fusion Program, Lawrence Livermore National Laboratory, USA

Library, General Atomics, USA

Plasma Physics Group, Fusion Energy Research Program, University of California at San Diego, USA

Plasma Physics Library, Columbia University, USA

Alkesh Punjabi, Center for Fusion Research and Training, Hampton University, USA

Dr. W.M. Stacey, Fusion Research Center, Georgia Institute of Technology, USA

Dr. John Willis, U.S. Department of Energy, Office of Fusion Energy Sciences, USA

Mr. Paul H. Wright, Indianapolis, Indiana, USA 
The Princeton Plasma Physics Laboratory is operated by Princeton University under contract with the U.S. Department of Energy.

\author{
Information Services \\ Princeton Plasma Physics Laboratory \\ P.O. Box 451 \\ Princeton, NJ 08543
}

Phone: 609-243-2750

Fax: 609-243-2751

e-mail: pppl_info@pppl.gov

Internet Address: http://www.pppl.gov 